\title{
Effects of biochar and peat on salt-affected soil extract solution and wheat seedling germination in the Yellow River Delta
}

Jie Wang, Guodong Yuan, Jian Lu, Jun Wu \& Jing Wei

To cite this article: Jie Wang, Guodong Yuan, Jian Lu, Jun Wu \& Jing Wei (2019): Effects of biochar and peat on salt-affected soil extract solution and wheat seedling germination in the Yellow River Delta, Arid Land Research and Management, DOI: 10.1080/15324982.2019.1696423

To link to this article: https://doi.org/10.1080/15324982.2019.1696423

曲 Published online: 10 Dec 2019.

Submit your article to this journal $\widetilde{ }$

Шll Article views: 5

Q View related articles $\longleftarrow$

View Crossmark data $\asymp$ 


\title{
Effects of biochar and peat on salt-affected soil extract solution and wheat seedling germination in the Yellow River Delta
}

\author{
Jie Wang ${ }^{\mathrm{a}, \mathrm{b}}$, Guodong Yuan ${ }^{\mathrm{a}, \mathrm{c}}$, Jian $\mathrm{Lu}^{\mathrm{a}, \mathrm{b}}$, Jun Wu${ }^{\mathrm{d}}$, and Jing Wei ${ }^{\mathrm{a}}$
}

${ }^{a}$ CAS Key Laboratory of Coastal Environmental Processes and Ecological Remediation, Yantai Institute of Coastal Zone Research (YIC), Chinese Academy of Sciences (CAS); Shandong Key Laboratory of Coastal Environmental Processes, YICCAS, Yantai Shandong, P. R. China; ${ }^{b}$ University of Chinese Academy of Sciences, Beijing, P. R. China; 'School of Environmental and Chemical Engineering, Zhaoqing University, Zhaoqing, P. R. China; ${ }^{\mathrm{d} S c h o o l}$ of Resources and Environmental Engineering, Ludong University, Yantai, Shandong, P. R. China

\begin{abstract}
Salt-affected soils are widely distributed in arable croplands, so it is important to reclaim these soils. In this study, the effects of different biochar/peat doses $(1,3$, and $5 \%)$ on 1:5 salt-affected soil: water extract solutions with different soil salinity levels after seven days shaking; and on winter wheat seedling growth after 80 hours are discussed. Results showed that the SAR and $\mathrm{Cl}^{-} / \mathrm{SO}_{4}{ }^{2-}$ ratio varied because of the changes of ion composition in the soil extract solution caused by the addition of biochar and peat. The maximum length of root and sprout of wheat grown in S1 (very slightly saline) soil extract treated by biochar/peat were $8.0 / 7.14$ and $4.86 / 4.50 \mathrm{~cm}$, respectively. The average length of wheat root and sprout grown in S2 (moderately saline) soil extract treated by peat was higher than that in soil treated by biochar. The results indicated that biochar and peat modified the ion composition of salt-affected soil extract solutions, as well as that of wheat. The abundant beneficial ions $\mathrm{K}^{+}$or $\mathrm{Ca}^{2+}$ in biochar/peat might be beneficial to reclaim the salt-affected soil, and the exogenous ions altered the composition of the soil solution to promote the seedling growth or enhance the resistance of plants to the salt stress. Moreover, cation exchange took place among soil, biochar/peat, and soil solution. The proportion of harmful $\mathrm{Na}^{+}$declined (SAR decreased) in the soil solution, which could be beneficial for the reclamation of the salt-affected soils.
\end{abstract}

\section{ARTICLE HISTORY}

Received 23 May 2019

Accepted 19 November 2019

\section{KEYWORDS}

Amelioration; biochar and peat; salt-affected soil; wheat germination; Yellow River Delta

\section{Introduction}

Salt-affected soils are distributed in arable croplands worldwide (Mahmoodabadi et al. 2013; Rengasamy 2006). It is estimated that nearly $9.32 \times 10^{8}$ ha of land is undergoing

CONTACT Jian Lu jlu@yic.ac.cn E CAS Key Laboratory of Coastal Environmental Processes and Ecological Remediation, Yantai Institute of Coastal Zone Research (YIC), Chinese Academy of Sciences (CAS), Yantai Shandong 264003, P. R. China; Shandong Key Laboratory of Coastal Environmental Processes, YICCAS, Yantai, Shandong 264003, P. R. China; $E$ Center for Ocean Mega-Science, Chinese Academy of Sciences, 7 Nanhai Road, Qingdao, 266071, P. R. China.

Color versions of one or more of the figures in the article can be found online at www.tandfonline.com/uasr. 
salinization and sodicity globally (Wong et al. 2010). Climate change, seawater intrusion, and unreasonable irrigation can trigger salinization.

The salt-affected soils usually show a poor soil structure with reduced hydraulic conductivity, aggregate stability, and aeration because of the excessive $\mathrm{Na}^{+}$in the soil solution or the exchange phase to cause clay swelling and dispersion (Rengasamy and Olsson 1991; Suarez, Wood, and Lesch 2006). Moreover, plant growth is inhibited by excessive salts, especially during the germination and seedling stage. High salt levels cause higher osmotic pressure of the soil solution, difficulty in water absorption, ion toxicity, and ion imbalance, which further reduces nutrient uptake (Amini et al. 2016; Meena et al. 2016).

Methods for ameliorating salt-affected soils mainly include drainage facilities, chemical amendments, and phytoremediation (Mau and Porporato 2016). Alternative solutions for ameliorating salt-affected soils are limited in areas with scarce water sources. Application of organic amendments is an option to improve soil fertility as well as benefit plants' salt tolerance. Biochar and peat, materials containing a large quantity of carbon, have attracted considerable attention as soil amendments.

Biochar is generally produced from residuals under the complete/partial absence of oxygen at temperatures ranging from $300^{\circ} \mathrm{C}$ to $1000^{\circ} \mathrm{C}$ (Lehmann 2007). Many studies have proved that biochar is capable of improving the properties of salt-affected soils (Drake et al. 2016; Ali et al. 2017; Abbas et al. 2018), enhancing the growth of such crops as beans and potatoes, contributing to antioxidant activities, increasing absorption of $\mathrm{K}^{+}$, and reducing $\mathrm{Na}^{+}$uptake (Akhtar, Andersen, and Liu 2015; Farhangi-Abriz and Torabian 2017). Peat, more like a slow-burning product, is produced by decay/decomposition of plants or organic matter (Joosten and Clarke 2002). Peat with a high content of humic acid often has large adsorption capacity, chelating, cation exchange capacity, and salt balance control, thereby enhancing physiology and the drought/disease resistance of crops after application.

The Yellow River Delta has a large amount of salt-affected land that has farming potential. Peat resources are abundant in the Yellow River Delta, while many agricultural wastes, such as straw and residuals/branches of fruit trees, could be made into biochar. Therefore, the application of biochar and peat can have important economic and practical significance for the improvement of salt-affected soils in this area. Although biochar and peat have been applied in ameliorating salt-affected soils, the mechanisms of ameliorating are not yet clear. A hypothesis was made in this study that different properties, such as $\mathrm{pH}$, specific surface, cation exchange capacity (CEC), and ion components of biochar and peat could have different effects on the amendment of salt-affected soil. It was assumed that the application of biochar and peat could modify the composition of the solute via dissolution and ion exchange to have a further impact on plant germination and growth. Therefore, in this study, a model experiment was conducted with extreme conditions on soils and wheat germination to clarify the expected changes.

\section{Materials and methods}

\section{Salt-affected soils, biochar, and peat}

The study area is located in the Yellow River Delta of China (N 37 $41^{\prime} 17.25^{\prime \prime}$, E $\left.118^{\circ} 36^{\prime} 03.76^{\prime \prime}\right)$, which is a typical ecologically fragile region with obvious seasonal 
drought (Mao et al. 2016) with $78 \%$ of annual precipitation $(564 \mathrm{~mm}$ ) occurring from June to September (http://www.dongying.gov.cn/html/xzqy/index.html). Salt-affected topsoil $(0-20 \mathrm{~cm})$ samples were collected and coded as S1/S2/S3 in November 2016 after winter wheat sowing. Air-dried soils were crushed to pass through the $2 \mathrm{~mm}$ sieve. The $\mathrm{pH}$ of $\mathrm{S} 1 / \mathrm{S} 2 / \mathrm{S} 3$ was determined to be approximately $7.65 / 7.56 / 7.02$, all less than 8.5 . The electrical conductivity (EC) of $\mathrm{S} 1 / \mathrm{S} 2 / \mathrm{S} 3$ was $0.46 / 3.04 / 10.64 \mathrm{dS} / \mathrm{m}$ at a soil-liquid ratio of 1:5 and the converted ECe (soil saturation extract for EC analysis) was 3.51/ 17.02/81.08 according to a previous study (Shahid, Zaman and Heng 2018). Based on the USDA classes, as nonsaline (ECe $<2 \mathrm{dS} / \mathrm{m}$ ), very slightly saline (ECe $2-4 \mathrm{dS} / \mathrm{m}$ ), slightly saline (ECe 4-8 dS/m), moderately saline (ECe $8-16 \mathrm{dS} / \mathrm{m}$ ), and strongly saline (ECe $>16 \mathrm{dS} / \mathrm{m}$ ) (USSL Staff 1954), S2 was classified as moderately saline, because its EC was slightly higher than the threshold value of moderately saline class. S1 and S3 were classified as very slightly saline and strongly saline soil, respectively (Table 1). The texture of the soil was loam according to the taxonomy of the United States Department of Agriculture (USDA) (Shirazi and Boersma 1984). The organic matter content was $20.62 / 19.84 / 11.22 \mathrm{~g} / \mathrm{kg}$.

The biochar used in this study was derived from corn cobs with limited oxygen at $400{ }^{\circ} \mathrm{C}$, while the peat was purchased from Jia He Co., Ltd. (Heilongjiang Province, China, http://www.ljhhumicacid.com/ps-4.html). Both biochar and peat were dried at $40^{\circ} \mathrm{C}$, crushed by a crusher and agate mortar, and then passed through a $0.15 \mathrm{~mm}$ dry sieve.

\section{Experimental design}

Biochar and peat were selected to amend salt-affected soils (S1, S2, and S3). After considering the cost and results of previous studies (Luo et al. 2016; Zhang et al. 2018) in the Yellow River Delta, four application doses (Control, T1, T2, and T3 treatments, with 1,3 and $5 \%$ amendment, respectively) using three replicates were utilized. Soil or soil-amendment mixtures with weight of $8 \mathrm{~g}$ and $40 \mathrm{ml}$ of deionized (DI) water were placed in a $50 \mathrm{ml}$ centrifugal tube. Therefore, soil-liquid ratio was $1: 5$, and the liquid extract was filtered by a $0.45 \mu \mathrm{m}$ membrane after being shaken at $300 \mathrm{rpm} / \mathrm{min}$ for seven days. In addition, pure biochar/peat was also treated according to the same procedure.

Given that wheat is one of the main food crops in this area, germination tests of winter wheat were performed to evaluate the effect of biochar and peat on ameliorating salt-affected soils. The soils (S1, S2, and S3) were mixed with the amendments at $0 \%$ (CK, control), 1\% (T1), 3\% (T2), and 5\% (T3) dose and $20 \mathrm{~g}$ of amended soil was placed on the surface of Petri dishes. Deionized water was sprayed to reach the soil water content of $20 \%$ and the treated soils were incubated for three days before germination under air-permeable membrane cover to prevent water evaporation. The winter wheat (Ji mai \#22) seeds were soaked in $5 \% \mathrm{NaClO}_{3}$ for $5 \mathrm{~min}$ for disinfection. Afterward, 30 plump seeds were selected for each dish. The dishes were placed in an artificial climate chest at $23^{\circ} \mathrm{C}$ for $80 \mathrm{~h}$. The lengths of root and sprout, as well as germination ratio, were determined at the end of the experiment. Seeds having roots at least $2 \mathrm{~mm}$ long were considered as germinated. 


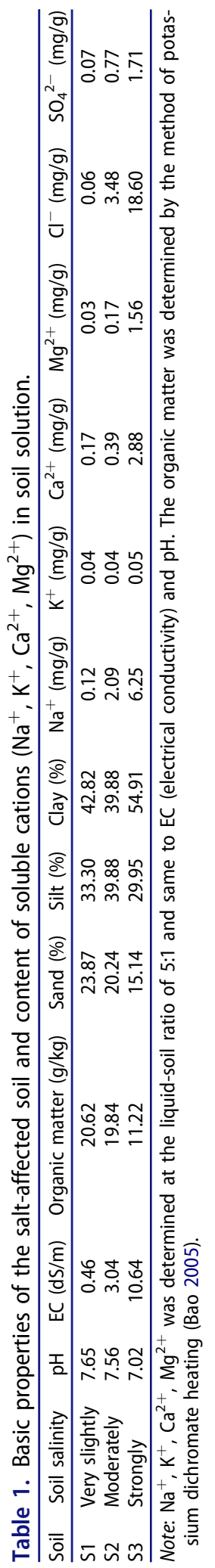


After germination, wheat seedlings were cleaned with DI water and dried using absorbent paper. A certain number of fresh wheat seedlings were cut into approximately $0.3 \mathrm{~cm}$ length, $10 \mathrm{ml}$ of DI water was added, boiled for $10 \mathrm{~min}$, and then filtered with a $0.45-\mu \mathrm{m}$ filter membrane. Concentrations of cations $\left(\mathrm{Na}^{+}, \mathrm{Ca}^{2+}, \mathrm{Mg}^{2+}\right.$, and $\left.\mathrm{K}^{+}\right)$and anions $\left(\mathrm{Cl}^{-}\right.$and $\left.\mathrm{PO}_{4}{ }^{3-}\right)$ of the seedling extracts were determined.

\section{Analysis methods and data processing}

The soluble salt content of the soil extract solution was determined by the residual drying method, CEC was determined using a sodium acetate flame photometry method, the organic matter in the soil was determined by a potassium dichromate heating method, and the total mass of $\mathrm{Na}^{+}, \mathrm{Ca}^{2+}, \mathrm{Mg}^{2+}$, and $\mathrm{K}^{+}$in biochar and peat digestion extract was determined according to the $\mathrm{HNO}_{3}-\mathrm{HClO}_{4}-\mathrm{HF}$ method (Bao 2005). Soluble cations $\left(\mathrm{Na}^{+}, \mathrm{Ca}^{2+}, \mathrm{Mg}^{2+}\right.$, and $\left.\mathrm{K}^{+}\right)$and anions $\left(\mathrm{Cl}^{-}, \mathrm{SO}_{4}{ }^{2-}, \mathrm{NO}_{3}{ }^{-}\right.$, and $\left.\mathrm{PO}_{4}{ }^{3-}\right)$ of soil extract solution, biochar, peat, or plant extracts were analyzed by ion chromatography (Dionex ICS3000, Dionex Corporation, USA). The contents of $-\mathrm{COOH}$ and phenol $-\mathrm{OH}$ in biochar and peat were determined through a titration method provided by the International Humic Substances Society (http://humic-substances.org/). Image J was employed to measure the lengths of roots and sprouts. Germination was confirmed when the bud length exceeded half of the root length.

Data were analyzed by Origin 8.1, Excel 2003, and SPSS 19.0. One-way analysis of variance, followed by Duncan's multiple comparison test $(p<0.05)$, was performed to determine the difference of the soil analysis results.

The SAR was calculated by the Eq. (1) and the concentrations of the involved soluble cations were expressed in mmolc/l (Shaygan, Reading, and Baumgartl 2017).

$$
\mathrm{SAR}=\frac{\left[\mathrm{Na}^{+}\right]}{\sqrt{1 / 2 \times\left[\mathrm{Ca}^{2+}\right]+\left[\mathrm{Mg}^{2+}\right]}}
$$

The germination ratio was calculated by the Eq. (2).

Germination ratio $(\%)=\frac{\text { (number of germinated seeds within } 80 \mathrm{~h})}{(\text { total number of seeds })} \times 100$

\section{Results}

\section{Properties of biochar and peat}

The chemical compositions and basic properties of biochar and peat are presented in Table 2. The amount of $\mathrm{K}^{+}$, which plays an important role in crop growth, reached $18 \mathrm{mg} / \mathrm{kg}$ in the biochar digestion solution. Both amendments had abundant carbon to increase soil organic materials significantly, even when the application dose is small. Phenol $(-\mathrm{OH})$ and carboxyl $(-\mathrm{COOH})$ are important oxidized functional groups. They are involved in ion exchange capacity, absorption, and complexation (Saifullah et al. 2018) with the salt in soil solution.

The contents and composition of soluble ions in the biochar and the peat extract solution were different (Table 2). $\mathrm{Na}^{+}$and $\mathrm{K}^{+}$accounted for approximately $95 \%$ of the soluble 
Table 2. Chemical compositions and basic properties of biochar and peat.

\begin{tabular}{|c|c|c|c|c|c|c|c|c|c|c|c|}
\hline \multirow[b]{2}{*}{ Amendment } & \multicolumn{4}{|c|}{ Total mass $(\mathrm{mg} / \mathrm{g})$} & \multirow{2}{*}{$\begin{array}{c}-\mathrm{COOH} \\
(\mathrm{mol} / \mathrm{kg})\end{array}$} & \multirow{2}{*}{$\begin{array}{c}\text { Phenol-OH } \\
(\mathrm{mol} / \mathrm{kg})\end{array}$} & \multirow[b]{2}{*}{ Ash (\%) } & \multirow[b]{2}{*}{ C (\%) } & \multirow[b]{2}{*}{ N (\%) } & \multirow[b]{2}{*}{ H (\%) } & \multirow[b]{2}{*}{ S (\%) } \\
\hline & $\mathrm{Na}^{+}$ & $\mathrm{K}^{+}$ & $\mathrm{Ca}^{2+}$ & $\mathrm{Mg}^{2+}$ & & & & & & & \\
\hline Biochar & 7.81 & 18.84 & 19.00 & 5.38 & 1.85 & 1.63 & 64.02 & 46.92 & 0.58 & 3.07 & 0.14 \\
\hline Peat & 2.01 & 2.99 & 3.69 & 2.57 & 0.72 & 1.71 & 18.00 & 49.73 & 2.56 & 0.07 & 0.76 \\
\hline
\end{tabular}

(b) Water extract composition of biochar and peat

\begin{tabular}{lccccccccc}
\hline Water extracts & $\mathrm{Na}^{+}(\mathrm{mg} / \mathrm{g})$ & $\mathrm{K}^{+}(\mathrm{mg} / \mathrm{g})$ & $\mathrm{Ca}^{2+}(\mathrm{mg} / \mathrm{g})$ & $\mathrm{Mg}^{2+}(\mathrm{mg} / \mathrm{g})$ & $\begin{array}{c}\mathrm{Cl}^{-} \\
(\mathrm{mg} / \mathrm{g})\end{array}$ & $\begin{array}{c}\mathrm{SO}_{4}{ }^{2-} \\
(\mathrm{mg} / \mathrm{g})\end{array}$ & $\begin{array}{c}\mathrm{CEC} \\
\mathrm{cmol} / \mathrm{kg}\end{array}$ & $\mathrm{pH}$ & $\mathrm{EC}(\mathrm{dS} / \mathrm{m})$ \\
\hline Biochar & 2.00 & 6.83 & 0.21 & 0.20 & 6.51 & 2.31 & 53.15 & 7.99 & 8.32 \\
Peat & 0.27 & 0.07 & 0.97 & 0.47 & 0.01 & 4.93 & 75.97 & 4.57 & 1.70 \\
\hline
\end{tabular}

Note: EC (electrical conductivity) and $\mathrm{pH}$ was determined at the liquid-soil ratio of 5:1. Total mass of was $\mathrm{Na}^{+}, \mathrm{K}^{+}$, $\mathrm{Ca}^{2+}, \mathrm{Mg}^{2+}$ determined according to $\mathrm{HNO}_{3}-\mathrm{HClO}_{4}-\mathrm{HF}$ method (Bao 2005); CEC (cation exchange capacity) was determined by a sodium acetate - flame photometry method (Bao 2005). $-\mathrm{COOH}$ and phenol-OH were important oxidized functional groups determined through titration method provided by the International Humic Substances Society (http://humic-substances.org/).

cations in the biochar water extract, while soluble cations in the peat extract mainly consisted of $\mathrm{Ca}^{2+}$ and $\mathrm{Mg}^{2+}$. Soluble $\mathrm{Cl}^{-}$and $\mathrm{SO}_{4}{ }^{2-}$ were the main anions in the water extracts of biochar and peat. Moreover, the water extract of biochar was alkaline $(\mathrm{pH}=7.99)$ because of the metal oxide, while that of peat was acidic $(\mathrm{pH}=4.87)$ in the presence of humic substances. High concentrations of soluble $\mathrm{Na}^{+}$and $\mathrm{K}^{+}$of biochar resulted in a much higher EC than that of peat, which probably caused the increase in soil EC after application.

The surface morphologies of biochar and peat are provided in Figures $1(a, b)$, respectively. The porous and carbonized plant tissues were shown in the surface morphology of biochar. The surface morphology of the peat was denser and more uniform. The oxygen-containing functional groups were the most characteristic groups for biochar and peat (Figure 1(c)). A large number of functional groups were present on the surface of biochar and peat, such as the carboxyl group with $\mathrm{C}=\mathrm{O}\left(1694 \mathrm{~cm}^{-1}\right)$, aromatic $\mathrm{C}=\mathrm{C}\left(1600 \mathrm{~cm}^{-1}\right)$, and $\mathrm{C}-\mathrm{H}\left(1000 \mathrm{~cm}^{-1}\right)$, which could contribute to ion exchange and form complexes with cations.

\section{$E C, p H$, and ion composition of soil extract solution}

EC is thought to relate positively to the concentration of soluble ions to reflect the salinity of saline soil roughly. The biochar and peat used in this experiment contained abundant water-soluble ions (Table 2), which resulted in an increase of soil EC $(p<0.05)$ in S1 (very slightly saline) and S2 (moderately saline) soils. The EC values of $\mathrm{S} 1$ and S2 soils with the amendments increased by $40-50 \%$ and $5-7 \%$, respectively. The effect of amendments on the EC of S3 (strongly saline) could be neglected because of the high background salt content, although a slight decrease in S3 was observed at high doses, which demonstrated the potential capacity of fixing soluble salts.

The soil $\mathrm{pH}$ indicates the acidity and alkalinity of soil and affects the growth of crops. Contrary to an earlier study that reported an increase in soil $\mathrm{pH}$ after biochar application (Saifullah et al. 2018), the addition of biochar did not significantly change the $\mathrm{pH}$ 
(a)

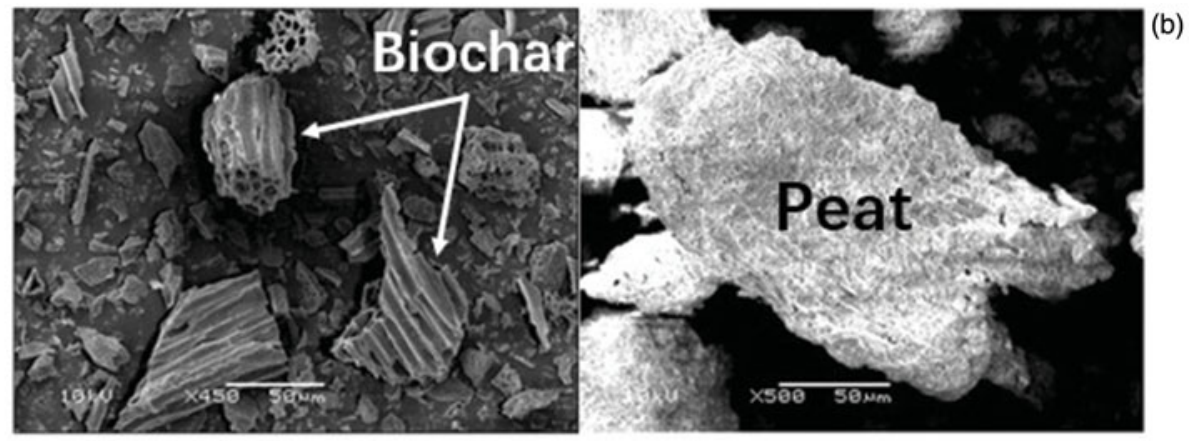

(c) 0.4

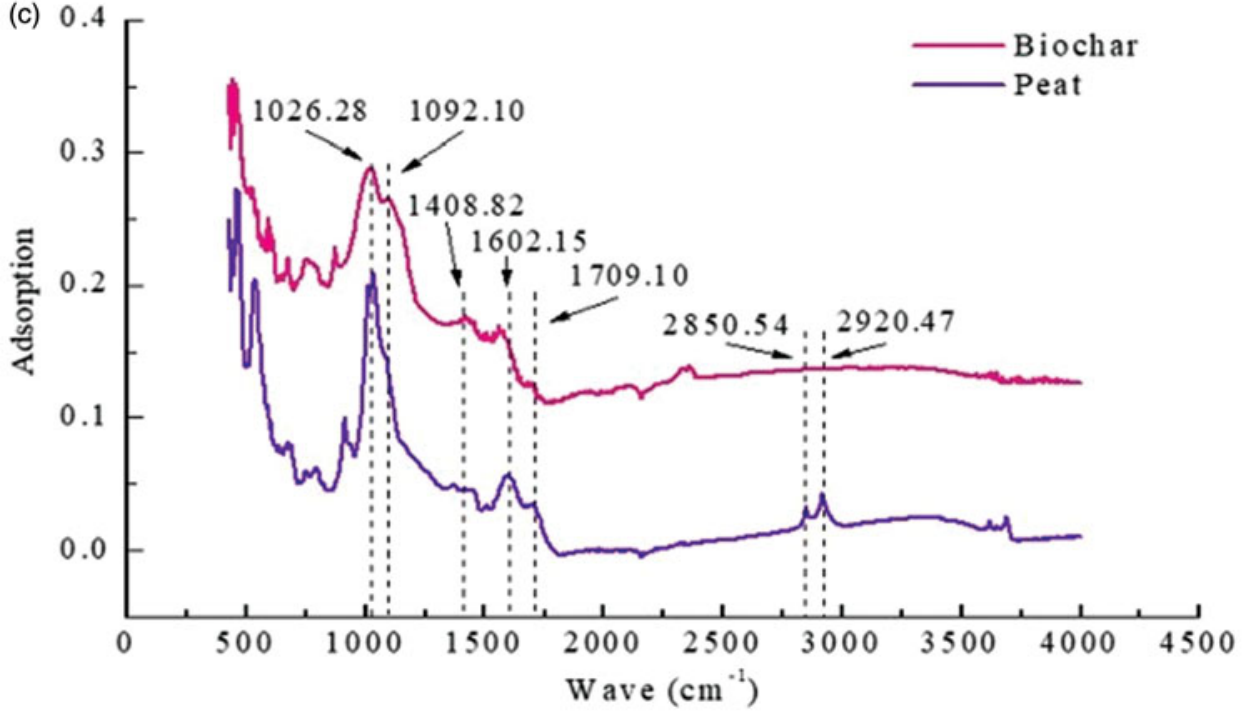

Figure 1. Scanning electron-microscope image of biochar (a) and peat (b) as well as FTIR of biochar and peat (c).

of salt-affected soils in this study (Figure 2). Peat with different addition doses changed the $\mathrm{pH}$ of soils by approximately 0.1 unit. The $\mathrm{pH}$ of soils in all treatments was below 8.0, indicating non-alkalinity of the soil.

The addition of the biochar or peat modified the ionic composition $\left(\mathrm{Na}^{+}, \mathrm{K}^{+}, \mathrm{Ca}^{2+}\right.$, $\mathrm{Mg}^{2+}, \mathrm{SO}_{4}{ }^{2-}$, and $\mathrm{Cl}^{-}$) and concentration of soil extract solutions (Figure 3). The results showed that the concentration of soluble $\mathrm{Na}^{+}$and $\mathrm{K}^{+}$was linear with the dose of biochar $\left(\mathrm{R}_{\mathrm{Na}}{ }^{2}=0.999 ; \mathrm{R}_{\mathrm{K}}^{2}=0.994\right)$. Concentrations of $\mathrm{Na}^{+}$and $\mathrm{K}^{+}$in $\mathrm{T} 3$ (at $5 \%$ addition dose) increased by 80 and $310 \%$ compared with CK. The divalent cations in the soil extract solution increased owing to abundant soluble and exchangeable $\mathrm{Ca}^{2+}$ and $\mathrm{Mg}^{2+}$ in peat. Concentrations of $\mathrm{Ca}^{2+}$ and $\mathrm{Mg}^{2+}$ doubled at the $5 \%$ addition of peat compared with $\mathrm{CK}$, reaching 2.4 and $0.76 \mathrm{mmol} / \mathrm{l}$, respectively. Changes of the cation composition in higher salinity S2 and S3 soil extract solutions were less affected by biochar and peat treatments (Figure 3). Furthermore, soluble $\mathrm{K}^{+}$and $\mathrm{Na}^{+}$increased with the addition of the biochar in S2 $\left(R_{\mathrm{K}}{ }^{2}=0.994 ; R_{\mathrm{Na}}{ }^{2}=0.870\right)$, while $\mathrm{Ca}^{2+}$ and $\mathrm{Mg}^{2+}$ increased with peat dose $\left(R_{\mathrm{Ca}}{ }^{2}=0.997 ; R_{\mathrm{Mg}}{ }^{2}=0.971\right)$. In addition, $\mathrm{Na}^{+}$content declined 

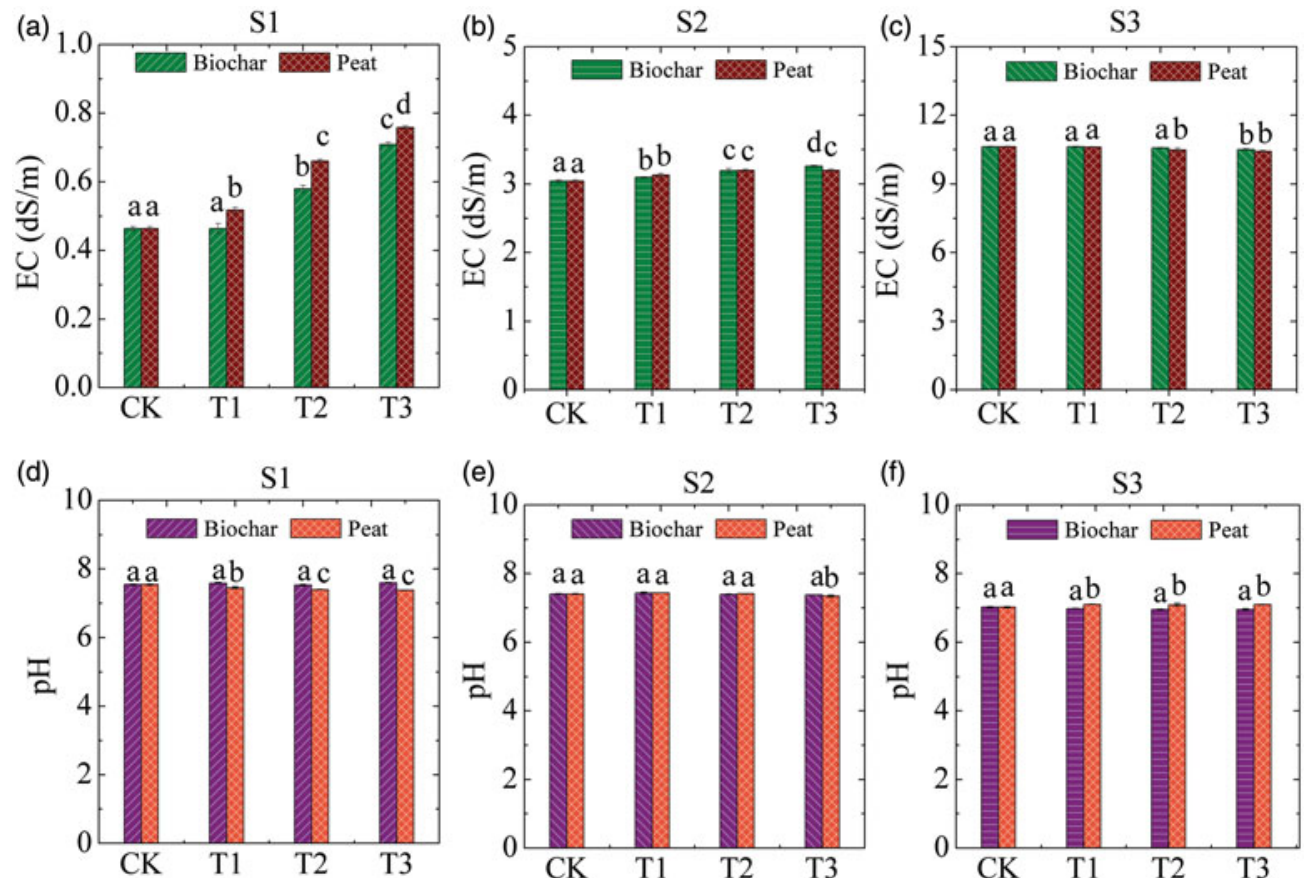

Figure 2. Variation of electrical conductivity (EC) and $\mathrm{pH}$ of the soil extract solutions. (a) $\mathrm{EC}$ variation of $\mathrm{S} 1$ soil by different treatments; (b) EC variation of S2 soil by different treatments; (c) EC variation of $\mathrm{S} 3$ soil by different treatments; (d) $\mathrm{pH}$ variation of $\mathrm{S} 1$ soil by different treatments; (e) $\mathrm{pH}$ variation of $\mathrm{S} 2$ soil by different treatments; ( $\mathrm{f}$ ) pH variation of $\mathrm{S} 3$ soil by different treatments. Note: $\mathrm{S} 1$ was the soil with very slight salinity; S2 was the soil with moderate salinity; S3 was the soil with strong salinity. T1 was the treatment of $1 \%$ dose; T2 was the treatment of 3\% dose; T3 was the treatment of $5 \%$ dose. Different lower case letters indicate significant differences between treatments at $p<0.05$. The extract was obtained after 7 days shaking at soil: water ratio of 1:5.

with peat dose $\left(R_{\mathrm{Na}}{ }^{2}=0.888\right)$ in $\mathrm{S} 2$. In $\mathrm{S} 3$, soluble $\mathrm{K}^{+}$was still affected by the addition of biochar, because the $R_{\mathrm{K}}^{2}$ was 0.990 .

Biochar/peat increased/decreased the SAR values of the salt extract solutions (Figure 4). The SAR of S1 soil increased from 0.86 (CK) to 1.49 (T3) because of the introduction of $\mathrm{Na}^{+}$by the biochar. Compared with $\mathrm{S} 1$, biochar treatment had less impact on the SAR values of S2 and S3 soil extract solutions. $\mathrm{K}^{+}$in biochar provided necessary nutrients for plants. On the other hand, the released $\mathrm{Na}^{+}$increased the salt content and hazard to plants. Unlike the biochar, peat treatment increased the concentrations of $\mathrm{Ca}^{2+}$ and $\mathrm{Mg}^{2+}$ in $\mathrm{S} 1 / \mathrm{S} 2 / \mathrm{S} 3$ soil extract solutions to result thereby in the decline of the SAR. The results also indicated that the SAR values of S1/S2/S3 soil extract solutions decreased with the dose of peat and the maximum decline was obtained in the T3 treatment (addition dose of 5\%) by 15.1, 17.5, and 5.9\% compared to $\mathrm{CK}$ values, respectively.

Similar to cations, anions in soil extract solutions caused different changes in response to the application of biochar and peat (Figure 3). Concentrations of $\mathrm{Cl}^{-}$ increased in S1/S2/S3 soil extract solutions treated by biochar. In S1 soil extract solutions, the $\mathrm{Cl}^{-}$concentration significantly increased from 0.38 to $2.76 \mathrm{mmol} / \mathrm{l}$ at a biochar dose of $5 \%$, while concentrations of $\mathrm{Cl}^{-}$in soil extract solution treated by peat 
(a)

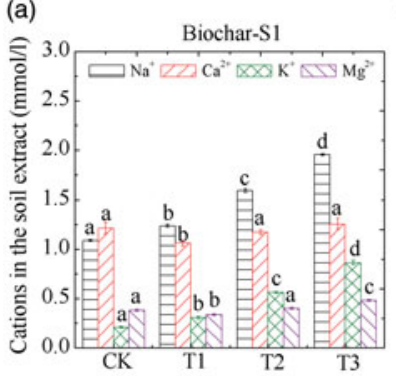

(d)

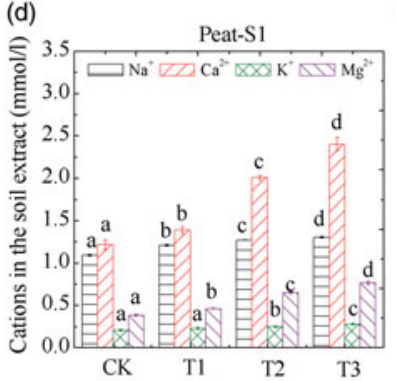

(g)
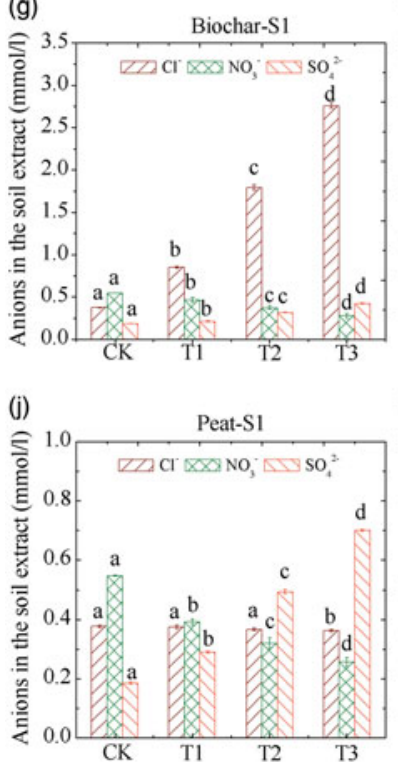

(b)

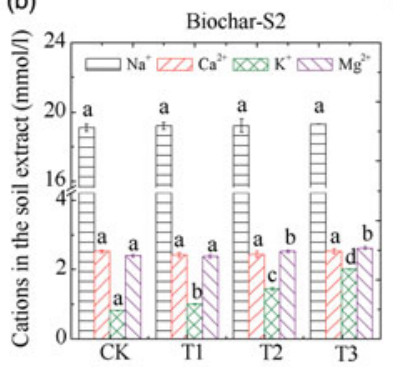

(e)

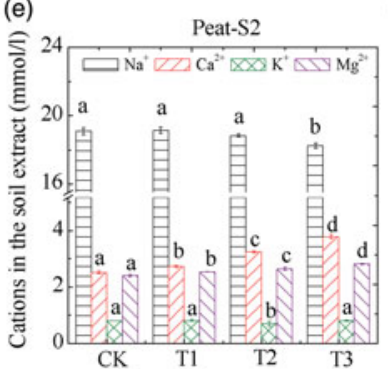

(h)

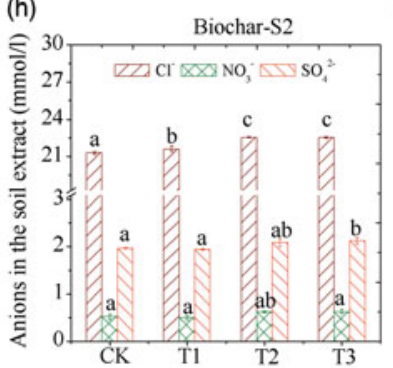

(k)

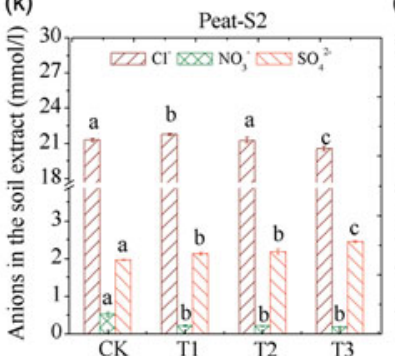

(c)

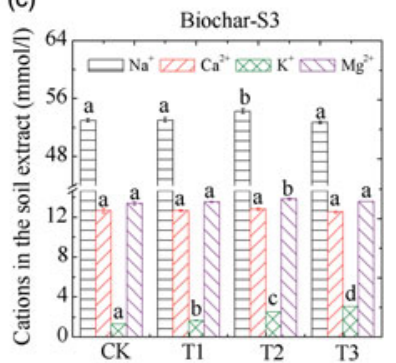

(f)

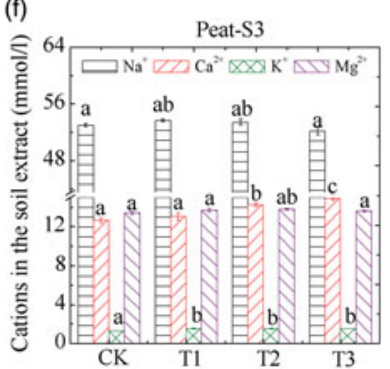

(i)

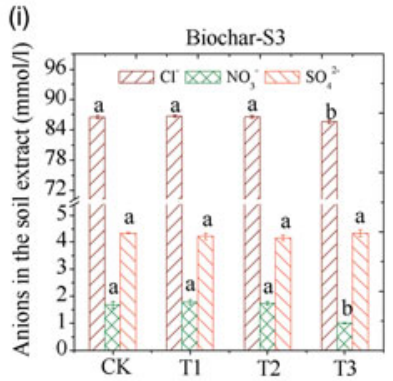

(I)

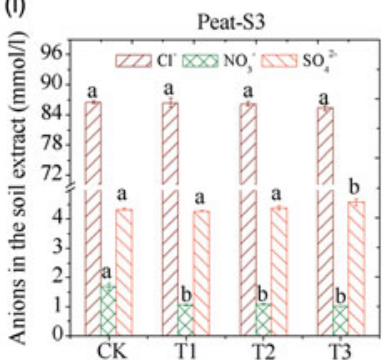

Figure 3. Variation of ions in the of $\mathrm{S} 1-\mathrm{S} 2-\mathrm{S} 3$ soil extract solutions. (a) cation variation of S1 amended by biochar; (b) cation variation of S2 amended by biochar; (c) cation variation of S3 amended by biochar; (d) cation variation of S1 amended by peat; (e) cation variation of S2 amended by peat; ( $\mathrm{f}$ ) cation variation of $\mathrm{S} 3$ amended by peat; $(\mathrm{g})$ anion variation of $\mathrm{S} 1$ amended by biochar; (h) anion variation of S2 amended by biochar; (i) anion variation of S3 amended by biochar; (j) anion variation of $\mathrm{S} 1$ amended by peat; ( $\mathrm{k}$ ) anion variation of $\mathrm{S} 2$ amended by peat; (I) anion variation of S3 amended by peat. Note: S1 was the soil with very slight salinity; $\mathrm{S} 2$ was the soil with moderate salinity; S3 was the soil with strong salinity. T1 was the treatment of $1 \%$ dose; T2 was the treatment of $3 \%$ dose; T3 was the treatment of 5\% dose. Different lower case letters indicate significant differences between treatments at $p<0.05$. The extract was obtained after 7 days shaking at soil: water ratio of 1:5. 

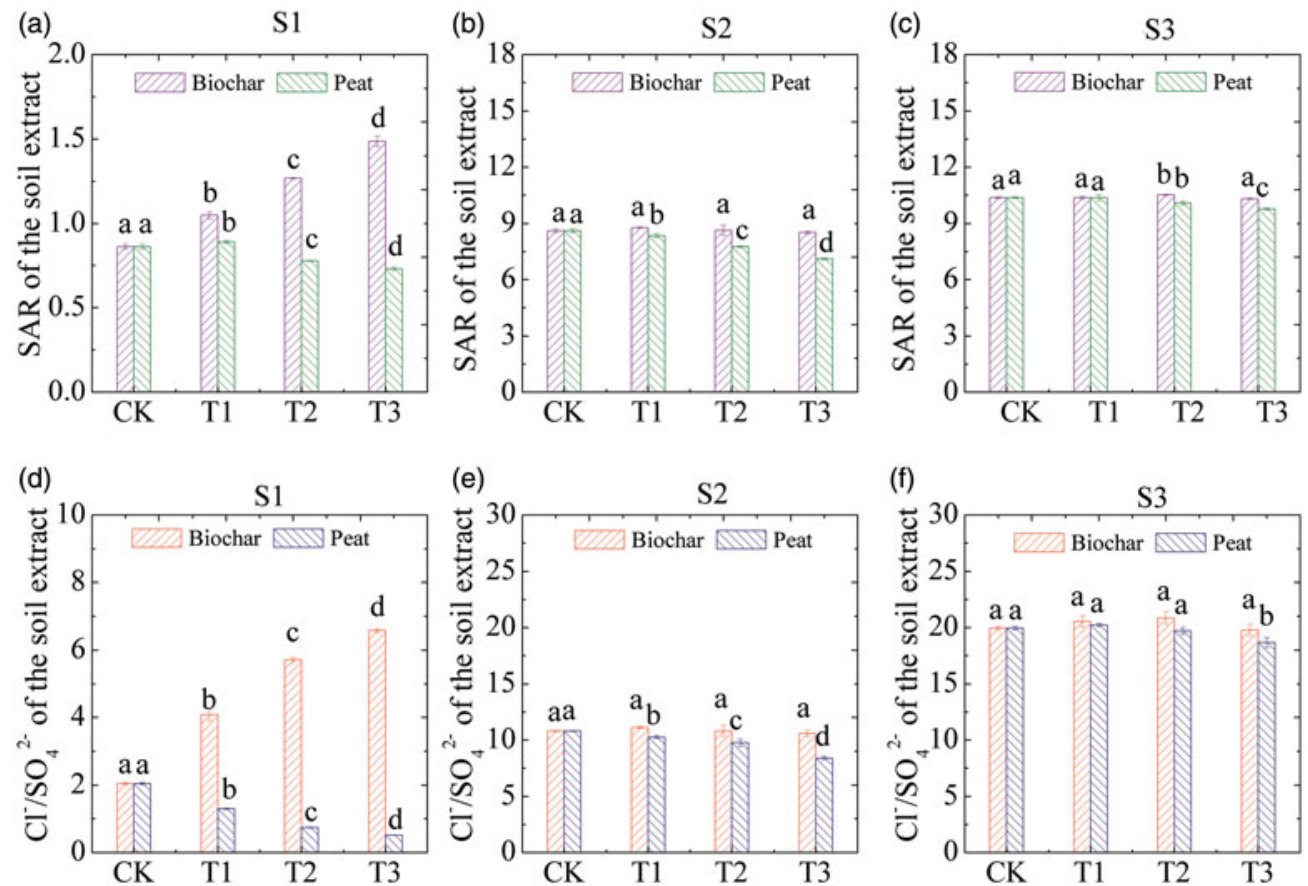

Figure 4. Sodium adsorption ratio $(\mathrm{SAR})$ and $\mathrm{Cl}^{-} / \mathrm{SO}_{4}{ }^{2-}$ of $\mathrm{S} 1-\mathrm{S} 2-\mathrm{S} 3$ soil extract solutions. (a) SAR variation in $\mathrm{S} 1$ by different treatments; (b) SAR variation in $\mathrm{S} 2$ by different treatments; (c) SAR variation in $\mathrm{S} 3$ by different treatments; (d) $\mathrm{Cl}^{-} / \mathrm{SO}_{4}{ }^{2-}$ variation in $\mathrm{S} 1$ by different treatments; (e). $\mathrm{Cl}^{-} / \mathrm{SO}_{4}{ }^{2-}$ variation in $\mathrm{S} 2$ by different treatments; $(\mathrm{f}) \mathrm{Cl}^{-} / \mathrm{SO}_{4}{ }^{2-}$ variation in $\mathrm{S} 3$ by different treatments. Note: $\mathrm{S} 1$ was the soil with very slight salinity; S2 was the soil with moderate salinity; S3 was the soil with strong salinity. T1 was the treatment of 1\% dose; T2 was the treatment of 3\% dose; T3 was the treatment of $5 \%$ dose. Different lower case letters indicate significant differences between treatments at $p<0.05$. The extract was obtained after 7 days shaking at soil: water ratio of 1:5.

were not affected. The application of biochar and peat increased the concentration of $\mathrm{SO}_{4}{ }^{2-}$ in S1 and S2 soil extract solutions. The concentration of $\mathrm{SO}_{4}{ }^{2-}$ in $\mathrm{S} 1$ and $\mathrm{S} 2$ soil extract solutions reached $0.42 / 0.70$ and $2.08 / 2.12 \mathrm{mmol} / \mathrm{l}$ in T3 (5\% dose) by biochar/ peat treatments, respectively. Only peat treatment had a significant impact on $\mathrm{SO}_{4}{ }^{2-}$ in the strongly saline soil-S3 soil extract solutions $(p<0.05)$, whose concentration of $\mathrm{SO}_{4}{ }^{2-}$ increased from $4.33(\mathrm{CK})$ to 4.58 (T3) mmol/l. The carbon-rich amendments decreased soluble $\mathrm{NO}_{3}{ }^{-}$in the soil extract solutions. The concentrations of $\mathrm{NO}_{3}{ }^{-}$in all applied salt-affected soil extract solutions declined with the dose of the peat, while the addition of the biochar only decreased nitrate concentration in S1 soil extract solutions.

The values of $\mathrm{Cl}^{-} / \mathrm{SO}_{4}{ }^{2-}$ ratio in $\mathrm{S} 1$ and $\mathrm{S} 2$ soil extract solutions increased with the addition of the biochar. The value of $\mathrm{Cl}^{-} / \mathrm{SO}_{4}{ }^{2-}$ ratio in $\mathrm{S} 1$ soil extract solutions showed a linear relationship with the biochar application dose $\left(R^{2}=0.91\right)$. The values of $\mathrm{Cl}^{-} / \mathrm{SO}_{4}{ }^{2-}$ in all soils were affected by the addition of the peat and the influence of the peat faded with the increase of soil salinity. The value of $\mathrm{Cl}^{-} / \mathrm{SO}_{4}{ }^{2-}$ in S1 soil extract solutions declined from 2.04 to 0.52 , while that in S2 soil extract solutions decreased from 10.82 to 8.39 with the addition of peat. A high background concentration of $\mathrm{Cl}^{-}$ in S3 (strongly saline) soil extract solutions weakened the effect of peat treatment, so 
that the peat amendment affected $\mathrm{Cl}^{-} / \mathrm{SO}_{4}{ }^{2-}$ ratio only at $5 \%$ dose. Moreover, $\mathrm{Cl}^{-}$in soils might be adsorbed or exchanged by the functional groups of the peat, which alleviated the harm of $\mathrm{Cl}^{-}$to wheat and resulted in a decline of $\mathrm{Cl}^{-} / \mathrm{SO}_{4}{ }^{2-}$ ratio.

\section{Growth of winter wheat}

The effects of biochar and peat on the germination of winter wheat were only investigated for S1 (very slightly saline) and S2 (moderately saline) soils (Figure 5). Winter wheat failed to germinate in S3 (strongly saline) soil, both in the presence and absence of amendments. The germination rate of winter wheat in S1 soil was relatively high and no significant difference was found among the different treatments $(p<0.05)$. The addition of biochar effectively increased the germination rate in S2 soil $(p<0.05)$. The wheat germination rate was $71.67 \% / 57.60 \%$ in $\mathrm{T} 1 / \mathrm{T} 2$ (treatment of 1 and $3 \%$ dose), while it was only $49.73 \%$ in CK. The addition of peat did not increase the germination rate of winter wheat in S1 and S2 soils $(p<0.05)$.

Both biochar and peat could increase wheat root and sprout growth in S1 soil. The longest root and sprout reached $8.04 / 7.14$ and $4.86 / 4.50 \mathrm{~cm}$ in S1 soil treated by the biochar/peat in T2 (treatment of 3\% dose), respectively. Because the salt from biochar and peat increased the salinity of the soil, T3 (treatment of 5\% dose) soil inhibited the growth of wheat compared with that in T2 soil. Statistically, peat had no impact on the root, but it increased the length of the sprout in T2 soil. Biochar had negative effects on the average length of the root/sprout of seedlings in S2 soil.

\section{Ion contents in early seedlings of winter wheat}

The ion $\left(\mathrm{Na}^{+}, \mathrm{K}^{+}, \mathrm{Ca}^{2+}, \mathrm{Mg}^{2+}, \mathrm{Cl}^{-}\right.$, and $\left.\mathrm{PO}_{4}{ }^{3-}\right)$ concentration of the wheat seedling extracts is shown in Figure $6 . \mathrm{Na}^{+}$and $\mathrm{K}^{+}$were the main cations in wheat seedling extract. In S1 (very slightly saline) soil, the concentration of $\mathrm{Na}^{+}$in wheat seedlings treated by biochar was lower than in those treated with peat. A large amount of $\mathrm{Na}^{+}$ entered the cytoplasm of plants, causing the lower germination ratio and hindering the development of root and sprout in S2 (moderately saline) soil (Figure 6). The content of $\mathrm{K}^{+}$in wheat seedling extract increased with the application of biochar/peat. $\mathrm{K}^{+}$content in wheat seedlings grown in S1 (very slightly saline) treated by biochar at a dose of $3 \%$ (T2) reached $3.45 \mathrm{mg} / \mathrm{g}$ and increased by $91.7 \%$ in comparison with CK treatment, while the highest $\mathrm{K}^{+}$content in seedlings grown in $\mathrm{S} 1$ treated by the peat at the $1 \%$ addition dose (T1) reached $4.10 \mathrm{mg} / \mathrm{g}$. The $\mathrm{K}^{+}$concentration in seedlings germinated in S2 (moderately saline) treated by the peat or biochar was higher than CK. The dose of biochar had no influence on $\mathrm{K}^{+}$in seedlings; no statistically significant difference was observed among $\mathrm{T} 1, \mathrm{~T} 2$, and $\mathrm{T} 3$ treatments. The $\mathrm{K}^{+} / \mathrm{Na}^{+}$ratio of soils treated with the amendments was generally higher than that of CK treatment. Biochar contained abundant potassium (Table 2), which provided sufficient $\mathrm{K}^{+}$for wheat seedlings to uptake. Therefore, the ratio of $\mathrm{K}^{+} / \mathrm{Na}^{+}$in seedlings treated by biochar was higher than in those treated by peat. The highest ratio of $\mathrm{K}^{+} / \mathrm{Na}^{+}$in $\mathrm{S} 1$ treated by biochar was 3.25 (Figure 6), nearly twice the maximum ratio obtained by peat (1.68). 

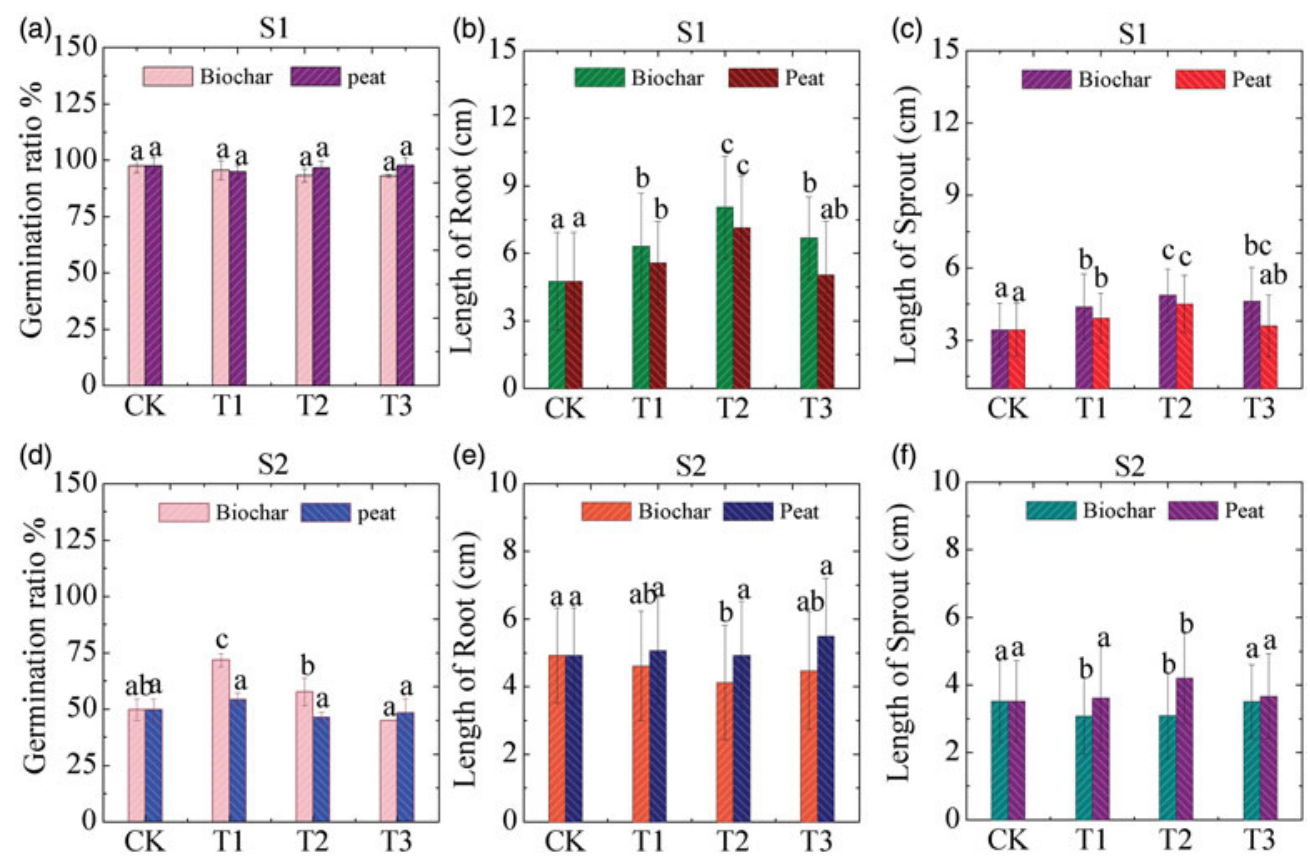

Figure 5. Germination ratio of wheat grown in S1(a) and S2 soils (d) under different treatments, root length of wheat grown in S1(b) and S2 (e) under different treatments and sprout length of wheat grown in S1(c) and S2 (f) under different treatments. Note: S1 was the soil with very slight salinity; S2 was the soil with moderate salinity. T1 was the treatment of $1 \%$ dose; T2 was the treatment of $3 \%$ dose; T3 was the treatment of $5 \%$ dose. Different lower case letters indicate significant differences between treatments at $p<0.05$. The extract was obtained after 7 days shaking at soil: water ratio of 1:5. The germination ratio, length of root and sprout was calculated or determined after 80 hours of growth.

Concentrations of $\mathrm{Ca}^{2+}$ and $\mathrm{Mg}^{2+}$ were lower than those of $\mathrm{Na}^{+}$and $\mathrm{K}^{+}$in seedling extracts (Figure 6). Biochar had no effect on concentrations of $\mathrm{Ca}^{2+}$ and $\mathrm{Mg}^{2+}$ in wheat seedlings in S1 soil, whereas concentrations of $\mathrm{Ca}^{2+}$ in seedlings grown in S2 soil treated by the biochar declined with the application dose $(p<0.05)$. The application of peat did not trigger any changes in $\mathrm{Ca}^{2+}$ concentration in seedlings statistically, except for the T3 (treatment of 5\%) in S2 (moderately saline). However, the concentration of $\mathrm{Mg}^{2+}$ in seedling extract treated by peat was higher than that in $\mathrm{CK}$.

Compared with $\mathrm{CK}$, the absorption of $\mathrm{Cl}^{-}$in the wheat seedlings, especially cultured in S1 was promoted by the application of biochar and peat to some extent. $\mathrm{Cl}^{-}$in the wheat seedlings cultured in S1 treated by biochar (Figure 6) increased with the added dose and the maximum concentration of $\mathrm{Cl}^{-}$reached $1.83 \mathrm{mg} / \mathrm{g}$. In peat treatment, the highest concentration occurred at a dose of $1 \%$ (T1) with $1.19 \mathrm{mg} / \mathrm{g}$. Biochar addition resulted in larger uptake of $\mathrm{Cl}^{-}$in wheat seedlings grown in S1 soil than in treatments with peat at the same addition dose (except $1 \%$ dose). The influence of biochar or peat addition on $\mathrm{Cl}^{-}$concentrations in S2 soil was less than that in S1 soil.

The concentration of $\mathrm{SO}_{4}{ }^{2-}$ in wheat seedlings grown in $\mathrm{S} 1$ and $\mathrm{S} 2$ treated with biochar or the peat was linearly (in S1: $R_{\text {biochar }}^{2}=0.93, R_{\text {Peat }}^{2}=0.73$; in S2: $R_{\text {biochar }}{ }^{2}=0.83$; $R_{\text {Peat }}{ }^{2}=0.87$ ) correlated with the dose (Figure 3 ). The phosphate content in wheat 
(a)

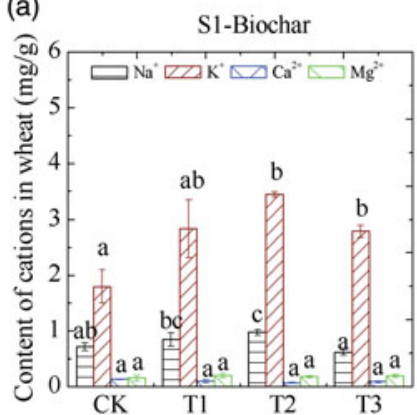

(d)

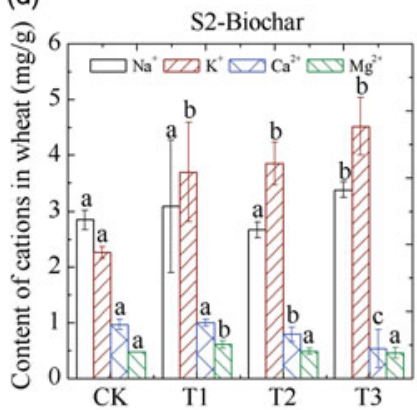

(g)

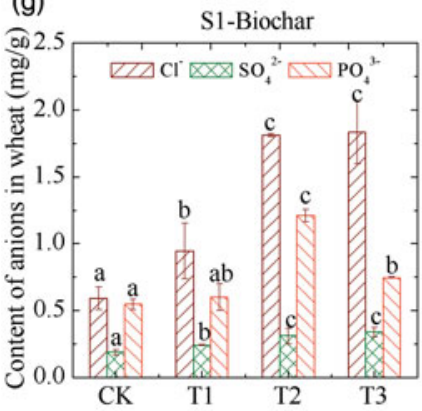

(j)

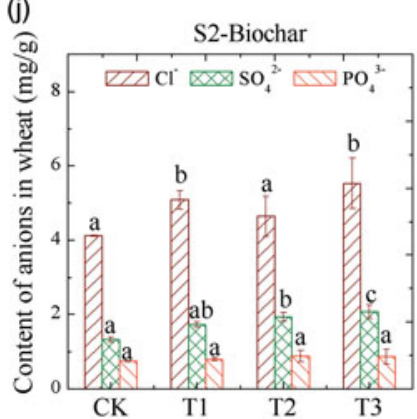

(b)

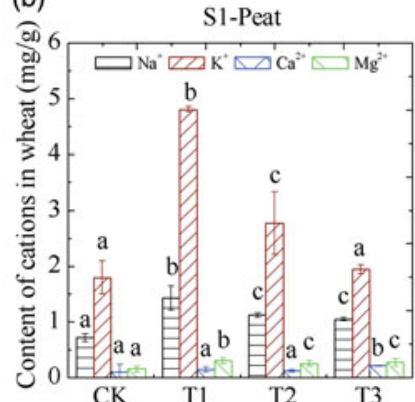

(e)

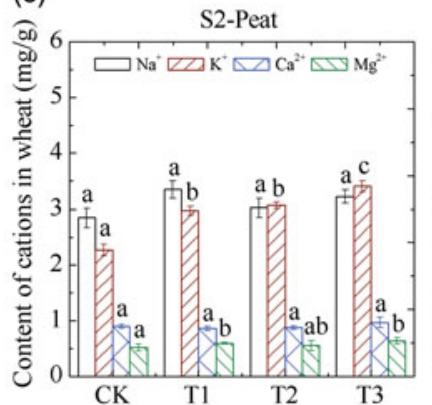

(h)

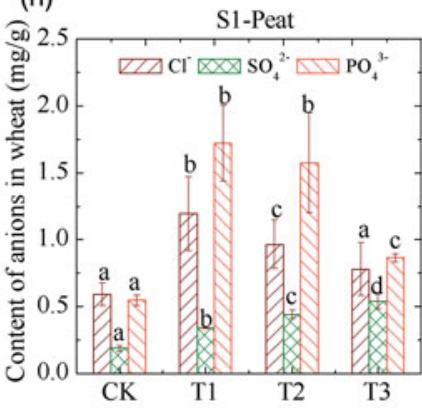

(k)

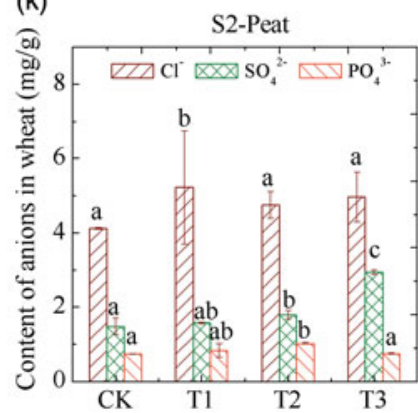

(c)

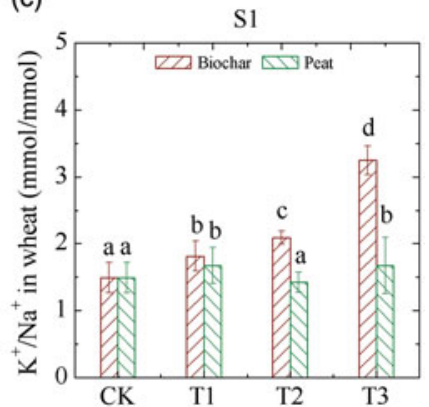

(f)

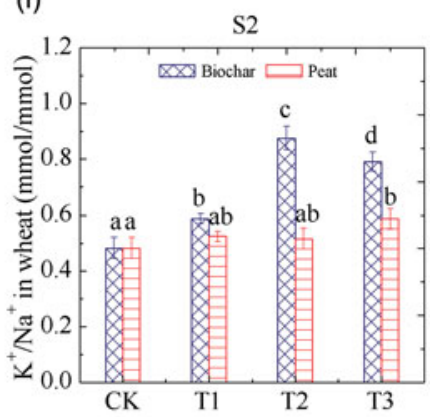

(i)

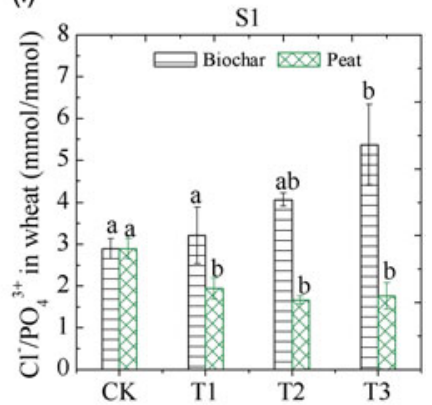

(I)

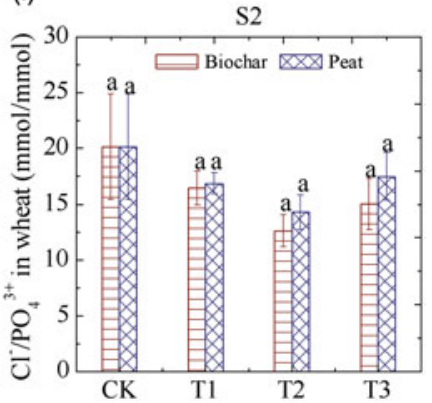

Figure 6. Cation contents of S1 amended by biochar (a) and peat (b), cation contents of S2 amended by biochar (d) and peat (e), anion contents of S1 amended by biochar (g) and peat (h), anion contents of S2 amended by biochar (j) and peat (k), $\mathrm{K}^{+} / \mathrm{Na}^{+}$ratio of S1 (c) and S2 (f), and $\mathrm{Cl}^{-} / \mathrm{PO}_{4}{ }^{3-}$ ratio of S1 (i) and S2 (I). Note: S1 was the soil with very slight salinity; S2 was the soil with moderate salinity. T1 was the treatment of 1\% dose; T2 was the treatment of 3\% dose; T3 was the treatment of $5 \%$ dose. Different lower case letters indicate significant differences between treatments at $p<0.05$. The extract was obtained after 7 days shaking at soil: water ratio of 1:5. The content of cations and anions in wheat were obtained through determining water extraction of wheat after 80 hours of growth. 
seedlings cultured in S1 soil reflected the biomass change (Figure 6). The addition of biochar in S2 increased the phosphate uptake of wheat seedlings and inhibited the accumulation of biomass. The application of peat did not have a significant influence on the phosphate of wheat seedling extracts among different doses. The relative concentration of $\mathrm{PO}_{4}{ }^{3-}$ and $\mathrm{Cl}^{-}$(mole ratio value of $\mathrm{Cl}^{-} / \mathrm{PO}_{4}{ }^{3-}$ ) in $\mathrm{S} 1$ treated by biochar increased by $86.1 \%$, while that in $\mathrm{S} 1$ treated by peat decreased by $39.1 \%$ in comparison with $\mathrm{CK}$ (Figure 6).

\section{Discussion}

\section{Effects of biochar and peat on salt-affected soils}

Biochar and peat differed in many properties, such as $\mathrm{pH}$, specific surface, CEC, and ionic composition. These differences might lead to different effects or mechanisms.

Many soluble ions existed in biochar and peat (Table 2). It was assumed that the ions in biochar (such as $\mathrm{K}^{+}$) and peat (such as $\mathrm{Ca}^{2+}$ and $\mathrm{Mg}^{2+}$ ) could alter the solute composition by the relevant processes of dissolution and ion exchange. The results in Figure 3 indicate that the concentration of $\mathrm{K}^{+}$increased in the soil extract solution after the application of biochar, whereas the concentration of $\mathrm{Ca}^{2+}$ and $\mathrm{Mg}^{2+}$ increased by the addition of peat. As organic amendments, both biochar and peat had a high CEC (Table 2), which made it possible to adsorb ions in the soil solution. Redistribution of ions in the soil-water system is affected by the addition of biochar and peat. It was deduced that the main cation exchange reactions might be the replacement of $\mathrm{Na}^{+}$in the soil solution by exchangeable $\mathrm{Ca}^{2+}$ in the amendments (Eq. 3) (Akhtar, Andersen, and Liu 2015) and the displacement of the exchangeable $\mathrm{Na}^{+}$of the soil particles by $\mathrm{Ca}^{2+}$ of the solution (Eq. 4).

$$
\begin{gathered}
\text { Amendment }-\mathrm{Ca}+2 \mathrm{Na}^{+} \leftrightarrow \text { Amendment }-\mathrm{Na}+\mathrm{Ca}^{2+} \\
\text { Soil }_{-\mathrm{Na}}^{-\mathrm{Na}+}+\mathrm{Ca}^{2+} \leftrightarrow \text { Soil }-\mathrm{Ca}+2 \mathrm{Na}^{+}
\end{gathered}
$$

The SAR, a common index that reflects the exchangeable sodium percentage, was used in this model experiment to clarify the changes in cations $\left(\mathrm{Na}^{+}, \mathrm{K}^{+}, \mathrm{Ca}^{2+}\right.$, and $\mathrm{Mg}^{2+}$ ) in soil solution. The results in Figure 4 demonstrate that the SAR value decreased with peat addition. $\mathrm{Ca}^{2+}$ and $\mathrm{Mg}^{2+}$ proved to facilitate the removal of $\mathrm{Na}^{+}$ from soil colloid by cation exchange reaction (Ghafoor et al. 2001; Bourrie 2014; Chaganti, Crohn, and Šimůnek 2015). However, abundant biochar led to a relative increase in the $\mathrm{K}^{+}$concentration in the extracts, which is beneficial, since soluble $\mathrm{K}^{+}$is regarded as a source of nutrient for crop growth (Abbasi, Anwar, and Raffaella 2015).

In addition to $\mathrm{Na}^{+}$, excessive $\mathrm{Cl}^{-}$is toxic to the growth of the plants in salt-affected soils of the Yellow River Delta (Teakle and Tyerman 2010; Luo et al. 2017; Xiong et al. 2018), while $\mathrm{SO}_{4}{ }^{2-}$ has a less harmful impact. Therefore, $\mathrm{Cl}^{-} / \mathrm{SO}_{4}{ }^{2-}$ ratio was used to evaluate the main anions in salt-affected soils. In this study, peat increased the concentration of $\mathrm{SO}_{4}{ }^{2-}$, and $\mathrm{Cl}^{-} / \mathrm{SO}_{4}{ }^{2-}$ failed to present a positive effect. 


\section{Effects of the amendments on the growth of winter wheat seedlings}

The application of biochar and peat modified the ion composition in soil extract solution and the ions subsequently were assumed to cause different effects on wheat seedling growth. The results in Figure 6 illustrate that $\mathrm{Na}^{+}$and $\mathrm{K}^{+}$were the main cations, with higher contents in the wheat seedlings than $\mathrm{Ca}^{2+}$ and $\mathrm{Mg}^{2+}$. The content of $\mathrm{K}^{+}$in wheat treated by biochar and peat was higher than that of $\mathrm{CK}$ treatment of $\mathrm{S} 1$ (very slightly saline) soil. A higher $\mathrm{K}^{+} / \mathrm{Na}^{+}$ratio in wheat seedlings treated by biochar and peat was also observed in the germination experiment. Also, the $\mathrm{K}^{+} / \mathrm{Na}^{+}$ratio treated by biochar was higher than by peat. Many studies have reported that $\mathrm{K}^{+}$was not only a key nutrient but also involved in many vital physiological processes. It has the capacity of reducing the uptake of $\mathrm{Na}^{+}$(Akhtar, Andersen, and Liu 2015; Lin et al. 2015). A high cytoplasmic $\mathrm{K}^{+} / \mathrm{Na}^{+}$ratio is critical to improve salt tolerance and reduce salt toxicity for many plant species (Chen et al. 2007; Arzani 2008). The length of root and sprout treated by biochar was longer than that treated by peat in S1 (very slightly saline) soil, which was similar to previous studies (Hao and Chang 2003; Pavlikova et al. 2017; El-Naggar et al. 2019). Therefore, it can be inferred that biochar and peat promote the ability of $\mathrm{K}^{+}$uptake for wheat. More $\mathrm{K}^{+}$was absorbed to enhance the development of wheat seedlings because of the sufficient $\mathrm{K}^{+}$amount provided by biochar.

The concentration of $\mathrm{Na}^{+}$in wheat seedlings cultured in S2 (moderately saline) soil was obviously higher than that in S1 (very slightly saline) soil, illustrating that $\mathrm{Na}^{+}$easily accumulated in wheat seedlings under salt stress. The influx of a large amount of $\mathrm{Na}^{+}$into the cytoplasm of plants probably increased osmotic pressure, which led to low germination and growth retardation (Figure 5). Moreover, the initial uptake of $\mathrm{K}^{+}$by crops aggravated the osmotic pressure. Previous studies (Miller et al. 2017; Saifullah et al. 2018) reported the potential harm of biochar to crops by increasing the salinity of soil. The germination rate of wheat seed in S2 soil treated by biochar increased, but the length of the sprout and root decreased compared with CK treatment. There was no significant difference between peat application and $\mathrm{CK}$ treatment on the germination rate of wheat and the length of the sprout/root. Therefore, it was inferred that the application of biochar in soils with moderate salinity might aggravate the salt stress to plants. The peat effect on plants in S2 soil was not observed in this study.

Concentrations of divalent cations $\left(\mathrm{Ca}^{2+}\right.$ and $\left.\mathrm{Mg}^{2+}\right)$ in wheat plants were much lower than those of monovalent cations $\left(\mathrm{Na}^{+}\right.$and $\left.\mathrm{K}^{+}\right)$. Calcium and magnesium were reported to participate in physiological and biochemical reactions in plants, such as forming cell membranes or composing protein complex (Demidchik et al. 2018). Ca/ Mg-dominated peat did not cause a significant difference of $\mathrm{Ca}^{2+}$ content in wheat $(p<0.05)$ among peat treatments and CK (Figure 6), although the concentration of $\mathrm{Ca}^{2+}$ in soil solution was largely affected by peat. However, $\mathrm{Ca}^{2+}$ content decreased with biochar dose in S2 (moderately saline) soil. The addition of biochar inhibited the uptake of $\mathrm{Ca}^{2+}$, which might partially explain why biochar retarded the root and sprout of the wheat.

$\mathrm{Cl}^{-}, \mathrm{SO}_{4}{ }^{2-}$, and $\mathrm{PO}_{4}{ }^{3-}$ were the major mineral anions in wheat (Figure 6). Biochar and peat altered the anion composition of wheat extracts. In S1 soil, the absorption of 
$\mathrm{Cl}^{-}$in the wheat was higher because of the $\mathrm{Cl}^{-}$concentration increased by biochar. Similarly, the application of peat contributed to the increase of $\mathrm{SO}_{4}{ }^{2-}$ concentration in the seedlings. The result demonstrated that anions in plants were related to the ion composition of the soil solution and the application of amendments (Figure 3). High soil salinity weakened the ability of amendment to alter the ion composition of the soil solution that could affect crops in the end.

\section{Conclusions}

This study was based on a model experiment to provide valuable information for the later field experiments in the Yellow River Delta. The process of interactions among biochar/peat, soil, and plants was expected to be clarified. Biochar and peat showed different effects on salt-affected soils because of their different predominating ion composition. An ion exchange reaction took place as the dissolution process altered the ionic composition of the soil solution. The index SAR and $\mathrm{Cl}^{-} / \mathrm{SO}_{4}{ }^{2-}$ ratio was significantly reduced in the soil solution treated by peat, while in that treated by biochar increased. Furthermore, the ions in wheat seedlings were affected, as well as the germination ratio and the lengths of roots and sprouts. Soluble $\mathrm{K}^{+}$was one of the dominating cations of biochar water extract and higher content of $\mathrm{K}^{+}$or $\mathrm{K}^{+} / \mathrm{Na}^{+}$in treatments of biochar demonstrated the uptake of $\mathrm{K}^{+}$. Compared with $\mathrm{K}^{+}$, the content of $\mathrm{Ca}^{2+}$ and $\mathrm{Mg}^{2+}$ was less, even in the treatments of peat whose soil solution was dominated by $\mathrm{Ca}^{2+}$ and $\mathrm{Mg}^{2+}$. Therefore, biochar was considered to impose more obvious effects on the wheat, while peat was modifying the soil solution.

Useful information was obtained for future field trials by analyzing the mechanism of biochar and peat in terms of their effects on the soil solution or crops. However, there were some limitations to this study. (1) The model experiment simplified the process of the dynamic change of water-salt in the field and the results might deviate from actual agricultural production. (2) To cover the salinity of the target field experiment area (the Yellow River Delta), the range of salinity is rather wide. More specific salinity range should be set up in future studies to match the salinity tolerance range of wheat. (3) Indicators (such as catalase) for evaluating germination and growth of wheat need to be used.

\section{Acknowledgments}

The authors would like to thank the reviewers for their valuable suggestions and comments on the manuscript.

\section{Funding}

This work was supported by the Chinese National Key Research and Development Program [2016YFD0200303], National Natural Science Foundation of China [41671319], Taishan Scholar Program of Shandong Province [No. tsqn201812116], One Hundred Talents Program of Chinese Academy of Sciences [Y629041021], and Two-Hundred Talents Plan of Yantai [Y739011021]. 


\section{References}

Abbas, T., M. Rizwan, S. Ali, M. Adrees, M. Zia-Ur-Rehman, M. F. Qayyum, Y. S. Ok, and G. Murtaza. 2018. Effect of biochar on alleviation of cadmium toxicity in wheat (Triticum aestivum L.) grown on Cd-contaminated saline soil. Environmental Science and Pollution Research 25 (26):25668-80. doi:10.1007/s11356-017-8987-4.

Abbasi, M. K., A. A. Anwar, and B. Raffaella. 2015. Ameliorating effects of biochar derived from poultry manure and white clover residues on soil nutrient status and plant growth promotion - greenhouse experiments. PLoS One 10 (6):e0131592. doi:10.1371/journal.pone.0131592.

Akhtar, S.S., M. N. Andersen, and F. Liu. 2015. Biochar mitigates salinity stress in potato. Journal of Agronomy and Crop Science 201 (5):368-78. doi:10.1111/jac.12132.

Ali, S., M. Rizwan, M. F. Qayyum, Y. S. Ok, M. Ibrahim, M. Riaz, M. S. Arif, F. Hafeez, M. I. Al-Wabel, and A. N. Shahzad. 2017. Biochar soil amendment on alleviation of drought and salt stress in plants: A critical review. Environmental Science and Pollution Research 24 (14): 12700-12. doi:10.1007/s11356-017-8904-x.

Amini, S., H. Ghadiri, C. Chen, and P. Marschner. 2016. Salt-affected soils, reclamation, carbon dynamics, and biochar: A review. Journal of Soils and Sediments 16 (3):939-53. doi:10.1007/ s11368-015-1293-1.

Arzani, A. 2008. Improving salinity tolerance in crop plants: A biotechnological view. In Vitro Cellular and Developmental Biology - Plant 44 (5):373-83. doi:10.1007/s11627-008-9157-7.

Bao, S. D. 2005. Soil agricultural chemistry analysis. 3rd ed. Beijing, China: China Agriculture Press (in Chinese).

Bourrie, G. 2014. Swelling clays and salt-affected soils: De-mixing of $\mathrm{Na} / \mathrm{Ca}$ clays as the rationale for discouraging the use of sodium adsorption ratio (SAR). Eurasian Journal of Soil Science (EJSS) 3 (4):245-53. doi:10.18393/ejss.12357.

Chaganti, V. N., D. M. Crohn, and J. Šimůnek. 2015. Leaching and reclamation of a biochar and compost amended saline-sodic soil with moderate SAR reclaimed water. Agricultural Water Management 158:255-65. doi:10.1016/j.agwat.2015.05.016.

Chen, Z., I. I. Pottosin, T. A. Cuin, A. T. Fuglsang, M. Tester, D. Jha, I. Zepeda-Jazo, M. Zhou, M. G. Palmgren, I. A. Newman., et al. 2007. Root plasma membrane transporters controlling $\mathrm{K}^{+} / \mathrm{Na}^{+}$homeostasis in salt stressed barley. Plant Physiology 145 (4):1714-25. doi:10.1104/pp. 107.110262.

Demidchik, V., S. Shabala, S. Isayenkov, T. A. Cuin, and I. Pottosin. 2018. Calcium transport across plant membranes: Mechanisms and functions. New Phytologist 220 (1):49-69. doi:10. 1111/nph.15266.

Drake, J., T. R. Cavagnaro, S. C. Cunningham, W. R. Jackson, and A. F. Patti. 2016. Does biochar improve establishment of tree seedlings in saline sodic soils. Land Degradation and Development 27 (1):52-59. doi:10.1002/ldr.2374.

El-Naggar, A., S. S. Lee, J. Rinklebe, M. Farooq, H. Song, A. K. Sarmah, A. R. Zimmerman, M. Ahmad, S. M. Shaheen, and Y. S. Ok. 2019. Biochar application to low fertility soils: A review of current status, and future prospects. Geoderma 337:536-54. doi:10.1016/j.geoderma.2018.09. 034.

Farhangi-Abriz, S., and S. Torabian. 2017. Antioxidant enzyme and osmotic adjustment changes in bean seedlings as affected by biochar under salt stress. Ecotoxicology and Environmental Safety 137:64-70. doi:10.1016/j.ecoenv.2016.11.029.

Ghafoor, A., M. Gill, A. Hassan, and M. Qadir. 2001. Gypsum: An economical amendment for amelioration of saline-sodic waters and soils and for improving crop yields. International Journal of Agriculture and Biology 9:266-75.

Hao, X., and C. Chang. 2003. Does long-term heavy cattle manure application increase salinity of a clay loam soil in semi-arid southern Alberta. Agriculture, Ecosystems and Environment 94 (1):89-103. doi:10.1016/S0167-8809(02)00008-7.

Joosten, H., and D. Clarke. 2002. Wise use of mires and peatlands. Saarijärvi, Finland: Saarijärven Offset Oy.

Lehmann, J. 2007. A handful of carbon. Nature 447 (7141):143-4. doi:10.1038/447143a. 
Lin, X. W., Z. B. Xie, J. Y. Zheng, Q. H. Liu, Q. C. Bei, and J. C. Zhu. 2015. Effects of biochar application on greenhouse gas emissions, carbon sequestration and crop growth in coastal saline soil. European Journal of Soil Science 66 (2):329-38. doi:10.1111/ejss.12225.

Luo, X., G. Liu, Y. Xia, L. Chen, Z. Jiang, H. Zheng, and Z. Wang. 2017. Use of biochar-compost to improve properties and productivity of the degraded coastal soil in the Yellow River Delta, China. Journal of Soils and Sediments 17 (3):780-9. doi:10.1007/s11368-016-1361-1.

Luo, X., L. Wang, G. Liu, X. Wang, Z. Wang, and H. Zheng. 2016. Effects of biochar on carbon mineralization of coastal wetland soils in the Yellow River Delta, China. Ecological Engineering 94:329-36. doi:10.1016/j.ecoleng.2016.06.004.

Mahmoodabadi, M., N. Yazdanpanah, L. R. Sinobas, E. Pazira, and A. Neshat. 2013. Reclamation of calcareous saline sodic soil with different amendments (1); redistribuation of soluble cations within the soil profile. Agricultural Water Management 120:30-38. doi:10.1016/j.agwat.2012.08. 018.

Mao, W., S. Kang, Y. Wan, Y. Sun, X. Li, and Y. Wang. 2016. Yellow river sediment as a soil amendment for amelioration of saline land in the Yellow river delta. Land Degradation and Development 27 (6):1595-602. doi:10.1002/ldr.2323.

Mau, Y., and A. Porporato. 2016. Optimal control solutions to sodic soil reclamation. Advances in Water Resources 91:37-45. doi:10.1016/j.advwatres.2016.02.014.

Meena, M. D., P. K. Joshi, B. Narjary, P. Sheoran, H. S. Jat, A. R. Chinchmalatpure, R. K. Yadav, and D. K. Sharma. 2016. Effects of municipal solid waste compost, rice-straw compost and mineral fertilizers on biological and chemical properties of a saline soil and yields in a mustard-pearl millet cropping system. Soil Research 54 (8):958-69. doi:10.1071/SR15342.

Miller, J., B. Beasley, C. Drury, F. Larney, and X. Hao. 2017. Surface soil salinity and soluble salts after 15 applications of composted or stockpiled manure with straw or woodchips. Compost Science and Utilization 25:36-47. doi:10.1080/1065657x.2016.1176968.

Pavlikova, D., V. Zemanova, K. Břendova, P. Kubatova, and P. Tlustos. 2017. Effect of biochar application on the content of nutrients $(\mathrm{Ca}, \mathrm{Fe}, \mathrm{K}, \mathrm{Mg}, \mathrm{Na}, \mathrm{P})$ and amino acids in subsequently growing spinach and mustard? Plant Soil and Environment 63 (7):322-7. doi:10.17221/318/ 2017-PSE.

Rengasamy, P. 2006. World salinization with emphasis on Australia. Journal of Experimental Botany 57 (5):1017-23. doi:10.1093/jxb/erj108.

Rengasamy, P., and K. A. Olsson. 1991. Sodicity and soil structure. Soil Research 29 (6):935-52. doi:10.1071/sr9910935.

Saifullah, S. Dahlawi, A. Naeem, Z. Rengel, and R. Naidu. 2018. Biochar application for the remediation of salt-affected soils: Challenges and opportunities. Science of the Total Environment 625:320-35. doi:10.1016/j.scitotenv.2017.12.257.

Shahid, S. A., M. Zaman, and L. Heng. 2018. Introduction to soil salinity, sodicity and diagnostics techniques. In Guideline for salinity assessment, mitigation and adaptation using nuclear and related techniques, 1-42. doi:10.1007/978-3-319-96190-3_1.

Shaygan, M., L. P. Reading, and T. Baumgartl. 2017. Effect of physical amendments on salt leaching characteristics for reclamation. Geoderma 292:96-110. doi:10.1016/j.geoderma.2017.01.007.

Shirazi, M. A., and L. A. Boersma. 1984. A unifying quantitative analysis of soil texture. Soil Science Society of America Journal 48 (1):142-7. doi:10.2136/sssaj1984.03615995004800010026x.

Suarez, D. L., J. D. Wood, and S. M. Lesch. 2006. Effect of SAR on water infiltration under a sequential rain-irrigation management system. Agricultural Water Management 86 (1-2): 150-64. doi:10.1016/j.agwat.2006.07.010.

Teakle, N. L., and S. D. Tyerman. 2010. Mechanisms of $\mathrm{Cl}^{-}$transport contributing to salt tolerance. Plant, Cell and Environment 33 (4):566-89. doi:10.1111/j.1365-3040.2009.02060.x.

USSL Staff. 1954. Diagnosis and improvement of saline and alkali soils. USDA Handbook No 60. Washington DC, USA: USDA.

Wong, V. N., R. Greene, R. C. Dalal, and B. Murphy. 2010. Soil carbon dynamics in saline and sodic soils: A review. Soil Use and Management 26 (1):2-11. doi:10.1111/j.1475-2743.2009. 00251.x. 
Xiong, F., J. R. Liao, Y. C. Ma, Y. H. Wang, W. P. Fang, and X. J. Zhu. 2018. The protective effect of exogenous putrescine in the response of tea plants (Camellia sinensis) to salt stress. Hortscience 53 (11):1640-6. doi:10.21273/HORTSCI13283-18.

Zhang, X., C. Chen, X. Chen, P. Tao, Z. Jin, and Z. Han. 2018. Persistent effects of biochar on soil organic carbon mineralization and resistant carbon pool in upland red soil, China. Environmental Earth Sciences 77 (5):177. doi:10.1007/s12665-018-7359-9. 